\title{
PENGARUH PENGGUNAAN KLOBOT JAGUNG SEGAR DALAM RANSUM TERHADAP KECERNAAN BAHAN KERING DAN BAHAN ORGANIK SERTA PRODUKSI KARKAS KELINCI PERANAKAN NEW ZEALAND WHITE JANTAN
}

\section{THE EFFECT OF FRESH CORNHUSK SUPPLEMENTATION IN THE DIET ON DRY MATTER AND ORGANIC MATTER DIGESTIBILITY AND CARCASS YIELD OF MALE NEW ZEALAND WHITE CROSSBRED RABBIT}

\author{
Risang Pramudyo Wardhana*, Fernandy Dwi Satrya, Sudiyono, dan Ratih Dewanti \\ Fakultas Pertanian, Universitas Sebelas Maret, Jl. Ir. Sutami 36A, Surakarta, 57126
}

\section{INTISARI}

Tujuan dari penelitian ini adalah mengetahui pengaruh penggunaan klobot jagung sebagai pengganti sebagian kangkung dalam ransum terhadap kecernaan bahan kering dan bahan organik serta produksi karkas kelinci Peranakan New Zealand White jantan. Penelitian ini dilaksanakan pada bulan Juni sampai Agustus 2013 di Balai Pembibitan dan Budidaya Ternak Non Ruminansia (BPBTNR) Surakarta. Penelitian ini menggunakan 16 ekor kelinci New Zealand White jantan berumur \pm 2 bulan dengan bobot badan awal 1301,69 $\pm 155,01$ g. Penelitian ini menggunakan Rancangan Acak Lengkap pola searah dengan 4 perlakuan dan 4 ulangan. Ransum basal disusun dari dedak halus, BR1 dan kangkung (Ipomoea aquatica). Keempat level perlakuan pakan tersebut adalah dedak halus $55 \%+\mathrm{BR} 125 \%+$ kangkung 20\% + klobot jagung 0\% (P0); dedak halus 55\% + BR1 25\% + kangkung 17,5\% + klobot jagung 2,5\% (P1); dedak halus 55\% + BR1 25\% + kangkung 15\% + klobot jagung 5\% (P2) dan dedak halus 55\% + BR1 25\% + kangkung $12,5 \%+$ klobot jagung 7,5\% (P3). Hasil penelitian menunjukkan bahwa penggunaan klobot jagung sampai level 7,5\% dari total ransum tidak berpengaruh terhadap kecernaan bahan kering dan bahan organik serta karkas kelinci Peranakan New Zealand White jantan.

(Kata kunci: Kelinci, Klobot jagung, Kecernaan bahan kering, Kecernaan bahan organik, Karkas)

\section{ABSTRACT}

The aim of this research was to observe the effect of fresh cornhusk supplementation in the diet on dry matter and organic matter digestibility and carcass yield of male New Zealand White Crossbred rabbit. The research was conducted at Balai Pembibitan dan Budidaya Ternak Non Ruminansia (BPBTNR) Surakarta, from June to August 2013. Sixteen male New Zealand White rabbits aged \pm 2 month were used in this research, with an initial body weight of $1301.69 \pm 155.01 \mathrm{~g}$. The research was design using a Oneway Completely Randomized Design with 4 treatments and 4 replications. The basal diet was composed of rice bran, BRI and water spinach (Ipomoea aquatic). The four levels of feeding treatments were, rice bran 55\% + BR1 25\% + water spinach $20 \%+$ cornhusk $0 \%$ (P0); rice bran 55\% + BR1 $25 \%+$ water spinach $17.5 \%+$ cornhusk $2.5 \%(P 1)$; rice bran 55\% + BR1 25\% + water spinach $15 \%+$ cornhusk $5 \%$ $(P 2)$ and rice bran 55\% + BR1 25\% + water spinach 12.5\% + cornhusk 7.5\% (P3). Results showed that the use of fresh corn husk in the diet up to $7.5 \%$ had no effect on dry matter and organic matter digestibility as well as carcass yield of male New Zealand White crossbred rabbit.

(Keywords: Rabbit, Cornhusk, Dry matter digestibility, Organic matter digestibility, Carcass)

\section{Pendahuluan}

Kelinci Peranakan New Zealand White mempunyai potensi sebagai alternatif penghasil daging, sebab kandungan proteinnya tinggi dan kolesterolnya lebih rendah dibanding daging ternak lainnya. Daging kelinci memiliki kadar protein yang lebih tinggi dibandingkan daging sapi dan domba (Rukmana, 2001). Faktor pakan merupakan salah satu faktor utama dalam mengembangkan ternak kelinci. Pakan kelinci terdiri dari dua jenis yaitu

\footnotetext{
* Korespondensi (corresponding author):

Telp. +62 82134693020

E-mail: risangpramudya@yahoo.co.id
}

pakan hijauan (rumput-rumputan, limbah sayuran dan legume) dan pakan konsentrat (pelet, bekatul, bungkil kelapa, bungkil kacang tanah, ampas tahu, ampas tapioka atau gaplek) (Sarwono, 2001).

Pemberian kangkung sebagai pakan tunggal pada kelinci telah banyak digunakan. Berdasarkan penelitian yang telah dilakukan Samkol et al. (2003), pemberian kangkung sebagai pakan tunggal sebanyak $8-18 \%$ dari bobot hidup dapat meningkatkan pertumbuhan meskipun kurang maksimal. Hal tersebut disebabkan karena kandungan serat kasar yang ada pada kangkung 
relatif rendah, sehingga perlu diberikan tambahan pakan yang memiliki kandungan serat kasar yang cukup tinggi.

Limbah pertanian dapat dipakai sebagai pakan kelinci untuk memenuhi kebutuhan serat kasar tersebut (Syamsu et al., 2003). Klobot jagung dapat dimanfaatkan sebagai pakan alternatif untuk meningkatkan kadar serat kasar pakan yang berbasis pada kangkung. Hasil analisis Laboratorium Uji Teknologi Pangan dan Hasil Pertanian, Fakultas Teknologi Pertanian, Universitas Gadjah Mada menunjukkan bahwa klobot jagung memiliki kandungan protein kasar 3,64\%, lemak kasar 0,64\%, dan serat kasar 29,05\%. Klobot jagung memiliki serat kasar yang tinggi tetapi protein rendah sedangkan kangkung memiliki serat kasar yang rendah tetapi memiliki protein yang lebih tinggi diharapkan campuran kedua bahan ini dapat mencukupi kebutuhan kelinci pada masa pertumbuhan.

Kelebihan lainnya adalah penggunaan klobot jagung sebagai pakan ternak tidak akan bersaing dengan kebutuhan manusia dan ketersediannya yang melimpah di berbagai musim. Persoalan yang sering dihadapi peternak dalam mengembangkan usahanya adalah ketersediaan hijauan yang sering berfluktuasi sebagaimana dinyatakan Utomo (2003), bahwa pengembangan peternakan mendapatkan kendala pada penyediaan hijauan pakan secara kontinyu sepanjang musim. Pergantian musim tentunya menyebabkan ketersediaan pakan akan berfluktuasi, di saat musim penghujan produksi mencukupi bahkan melimpah sementara musim kemarau produksinya terbatas.

Berdasarkan uraian tersebut maka peneliti tertarik untuk mengetahui pengaruh penggunaan klobot jagung untuk menggantikan sebagian kangkung dalam ransum terhadap kecernaan bahan kering dan bahan organik serta karkas kelinci New Zealand White jantan. Hipotesis dalam penelitian ini adalah penggunaan klobot jagung sampai level 7,5\% dalam ransum tidak berpengaruh terhadap kecernaan bahan kering dan bahan organik serta karkas kelinci Peranakan New Zealand White jantan.

\section{Materi dan Metode}

\section{Waktu dan tempat}

Penelitian dilaksanakan pada bulan Juni sampai Agustus 2013 di Balai Pembibitan dan Budidaya Ternak Non Ruminansia (BPBTNR) yang berlokasi di Jl. Balekambang Lor No. 3 Manahan, Kecamatan Banjarsari, Kota Surakarta. Analisis pakan dilaksanakan di Laboratorium Uji Teknologi Pangan dan Hasil Pertanian, Fakultas Teknologi Pertanian, Universitas Gadjah Mada, Yogyakarta.
Analisis sisa pakan dan feses dilaksanakan di Laboratorium Ilmu Nutrisi dan Makanan Ternak, Jurusan Peternakan, Fakultas Pertanian, Universitas Sebelas Maret, Surakarta.

\section{Bahan dan alat}

Ternak yang digunakan dalam penelitian adalah 16 ekor kelinci Peranakan New Zealand White jantan berumur \pm 2 bulan dengan rerata bobot badan $1301,69 \pm 155,01 \mathrm{~g}$. Kandang yang digunakan adalah kandang individu dengan ukuran 0,7 x 0,5 x $0,5 \mathrm{~m}^{3}$. Air minum yang diberikan kepada kelinci disimpan pada penampung air dan disalurkan ke masing-masing kandang menggunakan pipa yang dilengkapi dengan nipple. Peralatan lain yang digunakan selama penelitian adalah timbangan dan higrometer.

Pakan terdiri dari dedak halus dan bekatul dicampur dengan air hangat dan dibentuk kepalan. Klobot jagung yang diberikan yaitu lapisan ketiga dari lapisan terluar dan dipotong dengan ukuran \pm 1 $\mathrm{cm}$. Kangkung diangin-anginkan selama 8 jam sebelum diberikan untuk mengurangi kadar air. Pakan diberikan sebanyak dua kali sehari, yaitu pukul 07.00 dan 15.00 WIB. Air minum diberikan secara ad libitum.

\section{Pelaksanaan}

Penelitian ini dilakukan dengan menggunakan Rancangan Acak Lengkap pola searah. Keempat level perlakuan pakan tersebut adalah dedak halus 55\% + BR1 25\% + kangkung 20\% + klobot jagung $0 \%(\mathrm{P} 0)$; dedak halus $55 \%+\mathrm{BR} 1$ $25 \%$ + kangkung $17,5 \%$ + klobot jagung 2,5\% (P1); dedak halus 55\% + BR1 25\% + kangkung 15\% + klobot jagung 5\% (P2) dan dedak halus 55\% + BR1 $25 \%$ + kangkung 12,5\% + klobot jagung 7,5\% (P3).

Kelinci ditimbang seminggu sekali untuk mengetahui berat badannya dan untuk menyesuaikan jumlah ransum yang diberikan. Untuk mengetahui data kecernaan, dilakukan koleksi pakan, sisa pakan dan feses selama 1 minggu yang dilakukan pada minggu ke-7 pemeliharaan. Sebelum ternak diberi pakan, sisa pakan yang telah diberikan sehari sebelumnya dan feses masing-masing ternak dikumpulkan kemudian ditimbang untuk mengetahui berat feses dan diambil masing-masing 10\% sebagai sampel. Sampel yang diambil berupa pakan, sisa pakan, dan feses masingmasing ternak. Selama masa koleksi, sampel dikomposit dan dianalisis komposisi nutriennya secara proksimat (AOAC, 2005). Berdasarkan data jumlah pakan yang diberikan, sisa pakan, jumlah feses serta komposisi nutrien masing-masing dapat dihitung jumlah konsumsi nutrien dan nilai kecernaan nutrien pakan yang diberikan selama masa koleksi. Konsumsi pakan yang dihitung 
Tabel 1. Kandungan nutrien bahan pakan untuk ransum perlakuan (nutrient content of the treatment diet ingredients)

\begin{tabular}{lcccc}
\hline \hline \multicolumn{1}{c}{ Bahan pakan (feed stuff) } & $\begin{array}{c}\text { Gross energy } \\
(\mathrm{kcal} / \mathrm{kg})\end{array}$ & $\begin{array}{c}\text { Protein kasar } \\
(\%)(\text { crude } \\
\text { protein }(\%))\end{array}$ & $\begin{array}{c}\text { Lemak kasar } \\
(\%)(\text { crude } \\
\text { fat (\%)) }\end{array}$ & $\begin{array}{c}\text { Serat kasar (\%) } \\
\text { (crude fibre (\%)) }\end{array}$ \\
\hline Kangkung (Ipomoea aquatic) & $2846^{*}$ & 30,53 & 2,33 & 10,53 \\
Dedak halus (rice bran) & $2063^{*}$ & 9,63 & 5,40 & 22,51 \\
BR1 (broiler feed) & $2488^{*}$ & 24,94 & 5,78 & 3,11 \\
Klobot jagung (corn husk) & $3153^{*}$ & 3,64 & 0,64 & 29,05 \\
\hline
\end{tabular}

* DE $(\mathrm{MJ} / \mathrm{kg})=17,79-0,136 \mathrm{SK}-0,48 \mathrm{Abu}$ (Wiesemueller dan Leibetseder, 1993).

meliputi konsumsi bahan kering (BK) dan konsumsi bahan organik (BO). Kecernaan pakan yang dihitung meliputi kecernaan bahan kering (KcBK) dan kecernaan bahan organik (KcBO). Tahap selanjutnya pada minggu ke-8 dilakukan koleksi data untuk karkas, yaitu menimbang bobot badan kelinci pada akhir penelitian setelah dipuasakan 12 jam (Kartadisastra, 1997), menyembelih kelinci serta menimbang bobot potong, bobot karkas, bobot non karkas, serta menghitung persentase karkas dan non karkas.

Data yang diperoleh dianalisis menggunakan Rancangan Acak Lengkap pola searah.

\section{Hasil dan Pembahasan}

\section{Konsumsi bahan kering}

Konsumsi BK pada masing-masing perlakuan P0, P1, P2, dan P3 berturut-turut adalah 221,90; 213,34; 199,96; dan 219,02 g/ekor/hari (Tabel 3). Hasil analisis variansi menunjukkan bahwa penggunaan klobot jagung dalam ransum sampai level 7,5\% tidak mempengaruhi konsumsi BK kelinci Peranakan New Zealand White jantan. Hal ini mengindikasikan bahwa penggunaan klobot jagung sampai level 7,5\% masih cukup palatabel pada ransum kelinci Peranakan New Zealand White jantan. Hidayat dan Akbarillah (2009) menyatakan bahwa palatabilitas hijauan pakan dipengaruhi beberapa faktor, seperti: kandungan zat gizi dan material lain seperti racun, aroma, dan bahan lain. Paramita et al. (2008) menambahkan bahwa palatabilitas merupakan faktor utama yang menjelaskan perbedaan konsumsi BK antara pakan dan ternak-ternak yang berproduksi rendah. Selanjutnya dikatakan bahwa palatabilitas pakan umumnya berasosiasi dengan kecernaan yang tinggi dari suatu pakan. Tidak adanya zat anti nutrisi pada klobot jagung dan kangkung menyebabkan pakan ini lebih palatabel sehingga dapat mempengaruhi jumlah konsumsi pakan.

Penggunaan klobot jagung sampai level 7,5\% dari total ransum kelinci tidak mengubah kandungan energi dan protein ransum sehingga tidak mempengaruhi konsumsi BK ransum. Setiap pakan perlakuan yang diberikan memiliki kandungan energi yang hampir sama sehingga tidak memberikan pengaruh terhadap konsumsi pakan. Hal ini sesuai dengan Alhaidary et al. (2010) yang menyatakan bahwa semakin tinggi kandungan energi pada pakan dapat mengakibatkan rendahnya konsumsi pakan.

\section{Konsumsi bahan organik}

Konsumsi BO pada masing-masing perlakuan P0, P1, P2, dan P3 berturut-turut adalah 161,59; 157,29; 146,43; dan 162,29 g/ekor/hari (Tabel 3). Hasil analisis statistik menunjukkan bahwa penggunaan klobot jagung segar dalam ransum sampai level 7,5\% tidak mempengaruhi konsumsi BO pakan kelinci Peranakan New Zealand White jantan. Penggunaan klobot jagung dalam ransum kelinci sampai taraf 7,5\% memberikan konsumsi BK yang relatif sama, sedangkan BO merupakan bagian yang terkandung dalam $\mathrm{BK}$, sehingga konsumsi BO ransum juga tidak memberikan pengaruh. Sesuai dengan pendapat Cakra et al. (2005) yang menyatakan bahwa BO berkaitan erat dengan BK. Sebagaimana diketahui bahwa BO merupakan bagian terbesar dari BK, sehingga jumlah konsumsi BO sangat ditentukan oleh jumlah konsumsi BK pakan.

Fungsi utama klobot jagung dalam penelitian ini adalah melengkapi kebutuhan serat kasar pada kangkung yang belum dapat memenuhi kebutuhan kelinci jika hanya dipakai sebagai pakan tunggal. Serat kasar sendiri merupakan salah satu komposisi penyusun bahan organik. Hal ini sesuai dengan pendapat Putro (2010) yang menyatakan bahwa nutrien yang terkandung dalam BO merupakan komponen penyusun BK.

\section{Kecernaan bahan kering}

Kecernaan bahan kering pada masing-masing perlakuan P0, P1, P2, dan P3 berturut-turut adalah 57,19; 52,99; 53,28; dan 53,28\% (Tabel 3). Hasil analisis statistik menunjukkan bahwa penggunaan klobot jagung segar dalam ransum sampai level 
Risang Pramudyo Wardhana et al. Pengaruh Penggunaan Klobot Jagung Segar dalam Ransum terhadap Kecernaan

Tabel 2. Komposisi dan kandungan nutrien ransum perlakuan (diet composition and nutrient content of the treatment diet $)^{1}$

\begin{tabular}{lrrrr}
\hline \multirow{2}{*}{ Bahan pakan (feed stuff) } & \multicolumn{4}{c}{ Perlakuan (\%) (treatment (\%)) } \\
\cline { 2 - 5 } & $\mathrm{P} 0$ & \multicolumn{1}{c}{$\mathrm{P} 1$} & \multicolumn{1}{c}{$\mathrm{P} 2$} & \multicolumn{1}{c}{$\mathrm{P} 3$} \\
\hline Kangkung (Ipomoea aquatic) & 20,00 & 17,5 & 15,00 & 12,50 \\
Dedak halus (rice bran) & 55,00 & 55,00 & 55,00 & 55,00 \\
BR1 (broiler feed) & 25,00 & 25,00 & 25,00 & 25,00 \\
Klobot jagung (corn husk) & 0 & 2,50 & 5,00 & 7,50 \\
\hline Jumlah (total) & 100,00 & 100,00 & 100,00 & 100,00 \\
\hline Kandungan nutrient (nutrient content) & & & & \\
$\quad$ Gross energy (kcal/kg) & 2325,85 & 2333,53 & 2341,20 & 2348,88 \\
$\quad$ Protein kasar (\%) (crude protein (\%)) & 17,64 & 16,97 & 16,29 & 15,62 \\
Lemak kasar (\%) (crude fat (\%)) & 4,88 & 4,84 & 4,80 & 4,75 \\
Serat kasar (\%) (crude fiber (\%)) & 15,26 & 15,73 & 16,19 & 16,65 \\
\hline
\end{tabular}

${ }^{1}$ Hasil perhitungan berdasarkan Tabel 1 (the calculation based on the results of Table 1).

P0: dedak halus $55 \%+$ BR1 25\% + kangkung $20 \%+$ klobot jagung $0 \%$ (TO: rice bran $55 \%+$ BR1 $25 \%+$ water spinach $20 \%+$ cornhusk $0 \%$ ).

P1: dedak halus 55\% + BR1 25\% + kangkung 17,5\% + klobot jagung 2,5\% (T1: rice bran $55 \%+$ BR1 $25 \%$ + water spinach $17.5 \%+$ cornhusk $2.5 \%$ ).

P2: dedak halus 55\% + BR1 25\% + kangkung 15\% + klobot jagung 5\% (T2: rice bran 55\% + BR1 25\% + water spinach $15 \%+$ cornhusk $5 \%$ ).

P3: dedak halus 55\% + BR1 25\% + kangkung 12,5\% + klobot jagung 7,5\% (T3: rice bran 55\% + BR1 25\% + water spinach $12.5 \%+$ cornhusk $7.5 \%$ ).

Tabel 3. Rerata konsumsi bahan kering, konsumsi bahan organik, kecernaan bahan kering dan kecernaan bahan organik kelinci Peranakan New Zealand White jantan (average of dry matter intake, organic matter intake, dry matter digestibility and organic matter digestibility of male New Zealand White crossbred rabbits)

\begin{tabular}{|c|c|c|c|c|}
\hline \multirow{2}{*}{ Peubah (variable) } & \multicolumn{4}{|c|}{ Perlakuan (treatment) } \\
\hline & P0 & P1 & P2 & P3 \\
\hline $\begin{array}{l}\text { Konsumsi bahan kering (g/hari/ekor) (dry matter } \\
\text { intake }(\mathrm{g} / \text { day/head) })\end{array}$ & 221,90 & 213,34 & 199,96 & 219,02 \\
\hline $\begin{array}{l}\text { Konsumsi bahan organik (g/hari/ekor) (organic } \\
\text { matter intake (g/day/head)) }\end{array}$ & 161,59 & 157,29 & 146,43 & 162,29 \\
\hline $\begin{array}{l}\text { Kecernaan bahan kering }(\%) \text { (dry matter } \\
\text { digestibility }(\%))\end{array}$ & 57,19 & 52,99 & 53,28 & 53,28 \\
\hline $\begin{array}{l}\text { Kecernaan bahan organik (\%) (organic matter } \\
\text { digestibility }(\%))\end{array}$ & 40,68 & 39,41 & 36,62 & 39,93 \\
\hline \multicolumn{5}{|c|}{$\begin{array}{l}\text { P0: dedak halus } 55 \%+\text { BR1 } 25 \%+\text { kangkung } 20 \%+\text { klobot jagung } 0 \%(\text { T0: rice bran } 55 \%+\text { BR1 } 25 \%+ \\
\text { water spinach } 20 \%+\text { cornhusk } 0 \%) \text {. }\end{array}$} \\
\hline \multicolumn{5}{|c|}{$\begin{array}{l}\text { P1: dedak halus } 55 \%+\text { BR1 } 25 \%+\text { kangkung } 17,5 \%+\text { klobot jagung } 2,5 \% \text { (T1: rice bran } 55 \%+\text { BR1 } 25 \% \\
\quad+\text { water spinach } 17.5 \%+\text { cornhusk } 2.5 \%) \text {. }\end{array}$} \\
\hline \multicolumn{5}{|c|}{$\begin{array}{l}\text { P2: dedak halus } 55 \%+\text { BR1 } 25 \%+\text { kangkung } 15 \%+\text { klobot jagung } 5 \%(\text { T2: rice bran } 55 \%+\text { BR1 } 25 \%+ \\
\text { water spinach } 15 \%+\text { cornhusk } 5 \%) \text {. }\end{array}$} \\
\hline \multicolumn{5}{|c|}{$\begin{array}{l}\text { P3: dedak halus } 55 \%+\text { BR1 } 25 \%+\text { kangkung } 12,5 \%+\text { klobot jagung } 7,5 \%(\text { T3: rice bran } 55 \%+\text { BR1 } 25 \% \\
\quad+\text { water spinach } 12.5 \%+\text { cornhusk } 7.5 \%) \text {. }\end{array}$} \\
\hline
\end{tabular}

7,5\% tidak mempengaruhi KcBK kelinci Peranakan New Zealand White jantan. Hal ini karena kandungan protein yang rendah pada klobot jagung yaitu $3,64 \%$ dapat dilengkapi dengan tingginya kandungan protein yang ada pada kangkung yang mencapai 30,53\%. Rubianti et al. (2010) menyatakan bahwa protein merupakan suatu zat makanan yang penting bagi tubuh ternak dan tersedianya protein yang cukup menyebabkan aktivitas dan pertumbuhan mikroorganisme 
meningkat sehingga proses pencernaan dan konsumsi juga meningkat. Pendapat ini didukung oleh Oktarina et al. (2004) yang menyatakan bahwa peningkatan kadar protein dalam pakan akan meningkatkan laju perkembangbiakan dan populasi mikrobia rumen sehingga kemampuan mencerna pakan menjadi lebih besar.

Klobot jagung mempunyai serat kasar yang cukup tinggi jika dibandingkan dengan kangkung sehingga dapat melengkapi kebutuhan serat kasar kelinci. Namun demikian hasil dari penelitian ini yaitu penggunaan klobot jagung sumber serat kasar tidak memberikan pengaruh terhadap KcBK pakan. Anggorodi (1990) menyatakan bahwa tinggi rendahnya kecernaan pakan dipengaruhi oleh suhu lingkungan, laju perjalanan pakan melalui alat pencernaan, bentuk fisik bahan pakan, komposisi ransum, dan pengaruh terhadap perbandingan dari zat makanan lain.

\section{Kecernaan bahan organik}

Kecernaan bahan organik pada masingmasing perlakuan $\mathrm{P} 0, \mathrm{P} 1, \mathrm{P} 2$, dan $\mathrm{P} 3$ berturut-turut adalah 40,68; 39,41; 36,62; dan 39,93\% (Tabel 3). Hasil analisis statistik menunjukkan bahwa penggunaan klobot jagung segar dalam ransum sampai level 7,5\% tidak mempengaruhi $\mathrm{KcBO}$ kelinci Peranakan New Zealand White jantan. Hasil penelitian menunjukkan bahwa penggunaan klobot jagung dalam ransum sampai dengan level 7,5\% memberikan pengaruh yang sama baiknya terhadap nilai $\mathrm{KcBO}$ dengan ransum yang tidak diberikan klobot jagung (P0).

Hal ini menunjukkan bahwa penggunaan klobot jagung menggantikan sebagian kangkung pada perlakuan, tidak memberikan pengaruh pada setiap perlakuan. Kecernaan bahan organik ini sejalan dengan $\mathrm{KcBK}$, ini disebabkan karena $\mathrm{BO}$ tersebut merupakan bagian dari BK. Purnomo (2006) menyatakan bahwa tinggi rendahnya nilai KcBK pakan akan berpengaruh terhadap tingkat KcBO-nya. Pernyataan tersebut didukung oleh Mathius et al. (1991) yang menyatakan bahwa banyaknya BK yang dikonsumsi akan mempengaruhi besarnya nutrien yang dikonsumsi, oleh karena itu apabila BK yang dikonsumsi semakin banyak maka konsumsi BO juga meningkat begitu pula sebaliknya. Ransum yang diberikan pada tiaptiap perlakuan adalah sama, sehingga memiliki kandungan BK dan BO yang sama.

\section{Produksi karkas}

Hasil penelitian menunjukkan penggunaan klobot jagung segar tidak berpengaruh terhadap bobot potong, bobot karkas, bobot non karkas, persentase karkas, dan persentase non karkas (Tabel 4). Pemberian klobot jagung segar dalam ransum kelinci New Zealand White jantan tidak berpengaruh terhadap bobot karkas dapat dikarenakan kandungan nutrien pada masing-masing perlakuan tidak berbeda jauh dengan kebutuhan nutrien kelinci masa pertumbuhan. Kelinci masa pertumbuhan memerlukan digestible energy $2500 \mathrm{kcal} / \mathrm{kg}$, protein $12-16 \%, 2-5,5 \%$ dan serat kasar $12-20 \%$ Whendrato dan Madyana (1986). Kandungan nutrien perlakuan dari hasil analisis yaitu digestible energy 2325,85-2348,88 $\mathrm{kcal} / \mathrm{kg}$, protein 15,62-17,64\%, lemak kasar 4,75-4,88\%, dan serat kasar 15,26-16,65\%. Pemberian klobot jagung segar untuk menggantikan kangkung telah cukup untuk memenuhi kebutuhan nutrien pada kelinci. Hasil analisis kandungan nutrien ransum masingmasing perlakuan P0, P1, P2, dan P3 tidak berbeda jauh dengan kebutuhan nutrien kelinci masa pertumbuhan yang dapat dilihat pada Tabel 2 .

Bobot potong yang tidak berbeda menyebabkan berat karkas yang tidak berbeda pula. Berat karkas yang dihasilkan tergantung dari bobot hidup kelinci yang bersangkutan. Prasetiya (2010) menyatakan bahwa berat karkas sangat dipengaruhi bobot potongnya, sehingga berat karkas yang dihasilkan tergantung dari bobot potong kelinci yang bersangkutan. Faktor lain yang menyebabkan hasil tidak berpengaruh karena kandungan nutrien tiap perlakuan tidak berbeda jauh dan sudah cukup untuk pertumbuhan kelinci. Mujilah (2007) menyatakan bahwa terdapat kecenderungan proporsi bagian-bagian tubuh yang menghasilkan daging (kaki belakang, pinggang, dada, dan leher) akan bertambah besar sesuai dengan bertambahnya bobot badan, sehingga bobot karkas yang dihasilkan dipengaruhi oleh bobot potong dari ternak yang bersangkutan.

Hasil yang tidak berbeda terhadap persentase karkas ini diduga disebabkan oleh bobot potong kelinci yang juga berbeda tidak nyata. Persentase karkas adalah perbandingan antara bobot karkas dengan bobot potong, kemudian dikalikan 100 persen (Soeparno, 1999). Hal tersebut menyebabkan nilai persentase karkas sangat dipengaruhi oleh besarnya bobot potong dan bobot karkas, karena terdapat hubungan antara persentase karkas dan bobot potong. Kartadisastra (1997) menyatakan bahwa bobot karkas kelinci yang baik berkisar 40-52\% dari bobot badannya.

Faktor yang menyebabkan pemberian klobot jagung segar dalam ransum tidak berpengaruh terhadap bobot non karkas dapat disebabkan karena kandungan nutrien yang diberikan pada masingmasing perlakuan ransum yang diberi klobot jagung tidak berbeda dengan standar nutrien kelinci pada masa pertumbuhan. Hal ini diduga karena penambahan klobot jagung segar dalam ransum sampai level $7,5 \%$ belum mampu meningkatkan 
Paramita, W., W. E. Susanto, dan A. B. Yulianto. 2008. Konsumsi dan kecernaan bahan kering dan bahan organik dalam haylage pakan lengkap ternak sapi Peranakan Ongole. Media Kedokteran Hewan 24: 59-62.

Prasetiya, E. 2010. Pengaruh penggunaan tepung kulit buah kakao fermentasi dalam ransum terhadap produksi karkas kelinci. Skripsi S1. Fakultas Pertanian, Universitas Sebelas Maret. Surakarta.

Purnomo, H. 2006. Pengaruh pemberian urea molases blok (UMB) sebagai pakan suplemen terhadap kecernaan bahan kering dan bahan organik ransum kambing jantan. Skripsi S1. Fakultas Pertanian, Universitas Sebelas Maret. Surakarta.

Putro, G. A. 2010. Pengaruh suplementasi probiotik cair EM4 terhadap kecernaan bahan kering dan bahan organik ransum domba lokal jantan. Skripsi S1. Fakultas Pertanian, Universitas Sebelas Maret. Surakarta.

Rubianti. A., P. T. H. Fernandez, H. H. Marawali, dan E. Budisantoso. 2010. Kecernaan bahan kering dan bahan organik hay Clitoria ternatea dan Centrocema pascuorum $c v$ Cavalcade pada sapi Bali lepas sapih. Prosiding Seminar Nasional Teknologi Peternakan dan Veteriner. Pusat Penelitian dan Pengembangan Peternakan. Bogor.
Rukmana, R. 2001. Membuat Sosis: Daging Kelinci, Daging Ikan, Tempe Kedelai. Kanisius. Yogyakarta.

Samkol, P., T. R. Preston and J. Ly. 2003. Effect of Increasing Offer Level of Water Spinach (Ipomoea aquatica) on Intake, Growth and Digestibility Coefficients of Rabbits. Center for Livestock and Agriculture Development. Cambodia.

Sarwono, B. 2001. Kelinci Potong dan Hias. AgroMedia Pustaka. Jakarta.

Soeparno. 1999. Ilmu dan Teknologi Daging. Cetakan Pertama. Gadjah Mada Press. Yogyakarta.

Syamsu, J. A., K. Mudikjo, dan E. G. Sa'id. 2003. Daya dukung limbah pertanian sebagai sumber pakan ternak ruminansia di Indonesia. Wartazoa 13: 30-37.

Utomo, R. 2003. Penyediaan pakan di daerah tropik: Problematika, kontinuitas, dan kualitas. Pidato Pengukuhan Jabatan Guru Besar. Fakultas Peternakan, Universitas Gadjah Mada. Yogyakarta.

Whendrato, I. dan I. M. Madyana. 1986. Beternak Kelinci Secara Populer. Eka Offset. Semarang.

Wiesemueller, W. and J. Leibetseder. 1993. Ernaehrung Monogastrischer Nutztiere. Gustav Fisher Verlag Jena. Stuttgart. 